\title{
A general equilibrium assessment of climate change-induced loss of agricultural productivity in Nepal
}

\begin{abstract}
The impact of climate change on agriculture has been one of the most discussed topics in the literature on climate change. Multi-regional computable general equilibrium (CGE) models have frequently been used to examine the impact of climate change on agriculture. However, these studies do not focus on country-specific issues related to the link between climate change and agriculture. This paper aims to address this gap by investigating the economy-wide impacts of climate change on Nepalese agriculture. Nepal makes an interesting case study as it has one of the most vulnerable agricultural economies in South Asia. This paper develops a comparative static multi-household CGE model to trace the direct and indirect impacts of climate change in Nepal. The results suggest that climate change has a significant negative impact on the overall Nepalese economy due to the induced loss of agricultural productivity. The results further reveal that rural households in Nepal, whose livelihoods primarily depend on subsistence farming, will face additional climate change-induced stresses due to already overstrained poverty and a weak social welfare system. The results indicate an urgent need to mainstream adaptation strategies to lessen the negative impacts of any climate change-induced loss of agricultural productivity in Nepal.
\end{abstract}

Keywords: Climate change; agricultural productivity; impact assessment; general equilibrium; Nepal 


\section{Introduction}

A substantial volume of the literature on climate change brings attention to two major issues. First, human-induced climate change is unavoidable and is predicted to have a significant negative impact on many developing economies. Besides having consequences on the environment, climate change affects the resources that human life depends on. Importantly, the current and future impacts of climate change directly affect the welfare of the poor and vulnerable by damaging physical resources such as shelter and infrastructure through the increased frequency of flooding, storms and climate-related disasters (Garnaut, 2013; Nelson \& Shively, 2014).

Second, agricultural systems are heavily affected by negative impacts of climate variability, such as rises in annual temperature, erratic rainfall patterns and dimmed solar radiation, resulting in a decline in agricultural productivity. Extreme events, especially floods and droughts, have significant negative impacts on South Asian crop productivity and food supply (Bandara \& Cai, 2014, p. 452), which ultimately imposes upward pressure on food prices. The inclusion of food security features in the Paris Agreement as a part of a global climate change accord (UNFCCC, 2015, p. 20) not only confirms climate change impacts on food productivity but also presents challenge for maintaining food supply and demand in this over-populated part of the world (UNFCCC, 2015, Article 2b, p. 21).

Recent studies (eg., Cai, Bandara, \& Newth, 2016; Chhetri, Chaudhary, Tiwari, \& Yadaw, 2012; World Bank, 2012) agree that agriculture in South Asia is in a poor state due to anomalous floods, prolonged droughts, large-scale landslides and frequent and severe thunderstorms. Given the important contribution of agriculture to employment and people's livelihoods in South Asian countries, the loss of agricultural productivity due to climate change is of social and economic concern. Many other economic sectors besides agriculture are likely to experience the impacts of 
climate change, with negative effects on households' income and consumption. As a consequence of these threats, climate change imposes additional stresses to the social and economic challenges that the poorest households already face (IPCC, 2013). This situation accelerates their vulnerabilities as their livelihoods depend on climate-sensitive natural resources and their social welfare systems are weak. As a result, climate change increases their chances of falling into a cycle of poverty from which it is difficult to escape.

Of the countries in South Asia, Nepal is expected to be one of places most vulnerable to climate change. With regard to climate change parameters in Nepal, the regional climate-model projections show temperature increases of $1.6^{\circ} \mathrm{C}-2^{\circ} \mathrm{C}$ by $2030,2.3^{\circ} \mathrm{C}-2.9^{\circ} \mathrm{C}$ by 2050 , and $3.4^{\circ} \mathrm{C}-$ $5.0^{\circ} \mathrm{C}$ by 2080 (Ahmed \& Suphachalasai, 2014). If, as expected, agricultural productivity is significantly affected, this could have severe negative impacts on the Nepalese economy due to the crucial role of agriculture in household income and consumption. Agriculture generates around $74 \%$ of total employment in Nepal, contributing an average of $36 \%$ of gross domestic product (GDP) and at least 30\% of exports (CBS, 2014).

Although there is clear evidence that Nepal is highly vulnerable to climate change, few detailed studies have examined the effects of climate change on agricultural productivity in Nepal within a partial equilibrium modelling framework (eg., Chalise, Maraseni, \& Maroulis, 2015; Joshi, Maharjan, \& Piya, 2011; Poudel \& Kotani, 2013). Of those that have, it has been found that agricultural productivity in Nepal is likely to be severely affected by climate change. However, these studies have three important limitations. First, their results are skewed towards individual perceptions and practices, and the uncertainty and long timeframes associated with climate change limit the findings. Second, most of these studies emphasize crop production as a major factor in partial equilibrium analysis (Elbehri \& Burfisher, 2015), and disregard the direct and indirect linkages with the overall economy. Third, none of these studies look at climate change in relation to disparities between households in terms of income and expenditure. 
There are a few studies on the economy-wide impacts of climate change on agriculture. For example, Hertel, Burke, and Lobell (2010) employed a Global Trade Analysis Project (GTAP) model to evaluate the climate change-poverty nexus on a global scale. They found that the economic inefficiencies that are likely to be induced by climate change will impose extra trade imbalances in South Asian countries. Similarly, Bandara and Cai (2014) and Cai et al. (2016) attempted to evaluate the impacts of climate change on food crop productivity and provided a framework for an integrated assessment of food production economies in South Asia. Both studies claimed that unfavourable climate change is likely to exert upward pressure on food prices, which ultimately threatens food security in South Asia. Although the above mentioned studies attempted to assess climate change impacts on agriculture using global general equilibrium frameworks, the results are generalized for all South Asian countries. As such, they do not address country-specific climate change issues and impacts. More country-specific climate change studies are needed to investigate climate change-induced effects on agriculture and income distribution in vulnerable developing countries such as Nepal. There is clearly a gap in current literature for a specific study on Nepalese agriculture.

To this end, the main objective of this paper is to examine the economy-wide impacts of climate change-induced productivity loss in Nepalese crops. The rest of the paper is organized as follows: Section 2 provides a brief literature review on climate change and agricultural productivity in Nepal; Section 3 outlines the methodology, including the empirical model and framework; Section 4 presents the simulation results; and Section 5 discusses policy implications and offers some concluding remarks.

\section{Climate change and agricultural productivity in Nepal: A brief overview of literature}

Understanding climate status and its relationship with agricultural productivity is central to assessing the impacts of climate change on a particular crop. Moreover, it assists with the design 
of a framework of overall impacts on the Nepalese economy. Since agricultural productivity in Nepal primarily depends on seasonal rainfall patterns (the system of rain-fed farming dominates, at around $85 \%$ ), precipitation is a major factor that influences crop yields. Monsoons, in particular, provide around $80 \%$ of the annual rainfall (CBS, 2014). Although mean annual precipitation varies within the country and there is no definite trend in aggregate precipitation, there is evidence of extreme precipitation in Nepal. For example, in 2006, the mid-western lowlands (Terai) experienced heavy rains with flash floods, which damaged standing crops and reduced production by 30\% (Pokhrel \& Thapa, 2007). At the same time, the eastern part of Nepal faced extreme drought, which led to a decrease in rice production of $30 \%$ and a reduced crop production of $12.5 \%$ on a national basis (Malla, 2008). As a late or erratic monsoon quickly turns into crop damages and subsequent food insecurity, climate change influences large- and small-scale farming systems and brings about significant changes in crop-growing seasons, cropgrowth cycles and cropping patterns.

Another important cause of productivity loss is temperature rise, as heat waves impact the physiology of plants. Moreover, scientists have confirmed that an increase in temperature plays a great role in changing precipitation. Temperature records of Nepal from 1977 to 2009 show a general warming trend, with a $0.06^{\circ} \mathrm{C}$ increase in average annual temperature (Chalise, 2012). Some models predict an increase in temperature over Nepal that ranges from $0.5^{\circ} \mathrm{C}$ to $2.0^{\circ} \mathrm{C}$ in 2030 (NCVST, 2009). NAPA (2010) also suggests that days and nights are likely to become warmer than in the past. Specifically, the results of global circulation models (GCMs) suggest that the number of extremely hot days per annum (based on the hottest $5 \%$ of days for the period $1970-1999$ ) will increase by up to $55 \%$ by the 2060 s and $70 \%$ by the 2090 s (NCVST, 2009). Cline (2007) has projected temperature and daily precipitation in Nepal for 2080. The projections reveal that the daily temperature and daily precipitation in the monsoon months 
(June, July and August) is expected to increase markedly. This is likely to result in flash floods and landslides which will damage the agricultural system in Nepal.

Table 1 summarises a comprehensive literature survey on climate change impacts on Nepalese agriculture. According to Joshi et al. (2011), a time series regression analysis of 1977-2008 (see Table 1) shows a positive impact of climate variability, with increases in rice, wheat and maize of $1.7 \%, 2.32 \%$ and $1.49 \%$, respectively. However, a future projection on the basis of these results is not meaningful as climate change has non-linear impacts on crops, and technological advancement could have sole impacts in this case. Cline (2007) has reviewed the different approaches of various assessments and estimated the impacts of climate change on agricultural products globally by 2080 . Overall agricultural productivity in Nepal is estimated to decline by $17.3 \%$ if no adaptation and carbon fertilization strategies are implemented and current technological changes continue.

Similarly, in their literature survey, Knox, Hess, Daccache, and Perez Ortola (2011) have projected an average change in agricultural productivity in Africa and Asia that is more or less consistent with that of Hertel et al. (2010) and Bandara and Cai (2014). Hertel et al. (2010) have provided a range of productivity change for all the countries in the world. Some Indian-based studies $^{1}$ (such as Auffhammer, Ramanathan, \& Vincent, 2012; Byjesh, Kumar, \& Aggarwal, 2010; Kumar, 2011; Kumar \& Parikh, 2001) have predicted a range of significant productivity losses in Indian agriculture. Overall, some literature expects notably positive impacts of climate change in certain crops. For example, rice yields are expected to increase until 2030, and some assessments (e.g., Iglesias and Rosensweig (2010); Thapa and Joshi (2011) have projected a positive impact of climate change on rice and wheat until 2080. Despite these variations in estimates of productivity losses due to climate change in Nepalese agriculture, this study has used an average of low,

\footnotetext{
${ }^{1}$ A few studies on Indian agriculture were reviewed during this work as they reveal that Indian agriculture is similar to Nepalese farming in many respects (e.g., rain-fed agricultural system, level of technological advancement, and cropping-weather pattern).
} 
medium and high numbers of the estimations (see Table 1) for the modelling analysis described in the next section.

Table 1

Comprehensive literature survey on climate change impacts in Nepalese agriculture

\begin{tabular}{|c|c|c|c|c|c|}
\hline Source & Methodology & Crop & \multicolumn{3}{|c|}{ Productivity change $(\%)$} \\
\hline $\begin{array}{l}\text { Kumar and } \\
\text { Parikh (2001) }\end{array}$ & $\begin{array}{l}\text { Regression on net farm } \\
\text { revenue }\end{array}$ & All & \multicolumn{3}{|c|}{-8.4 (Projection in Indian crops- as of $+2^{\circ} \mathrm{C}$ ) } \\
\hline Cline (2007) & Integrating all models & All & \multicolumn{3}{|c|}{$\begin{array}{l}\text { Without carbon fertilization }=-17.3 \text { With } \\
\text { carbon fertilization and adaptation }=-4.8\end{array}$} \\
\hline $\begin{array}{l}\text { Iglesias and } \\
\text { Rosensweig } \\
\text { (2010) }\end{array}$ & $\begin{array}{l}\text { Crop simulations on the } \\
\text { basis of carbon dioxide } \\
\text { emission scenarios }{ }^{2}\end{array}$ & $\begin{array}{l}\text { Rice } \\
\text { Wheat } \\
\text { Maize }\end{array}$ & $\begin{array}{l}\frac{2020}{-2.23} \\
-7.55 \\
-7.75\end{array}$ & $\begin{array}{r}2050 \\
+2.70 \\
+9.58 \\
-10.91\end{array}$ & $\begin{array}{l}\frac{2080}{+6.67} \\
+9.37 \\
-4.98\end{array}$ \\
\hline $\begin{array}{l}\text { Hertel et al. } \\
(2010)\end{array}$ & $\begin{array}{l}\text { General equilibrium } \\
\text { analysis based on GTAP }\end{array}$ & $\begin{array}{l}\text { Rice } \\
\text { Wheat } \\
\text { Maize }\end{array}$ & $\begin{array}{l}\frac{\text { Low }}{-15} \\
-10 \\
-17\end{array}$ & $\begin{array}{c}\text { Medium } \\
-5 \\
-3 \\
-10\end{array}$ & $\begin{array}{c}\frac{\text { High }}{+4} \\
+4 \\
-3\end{array}$ \\
\hline Joshi et al. (2011) & $\begin{array}{l}\text { Time Series Regression } \\
\left(1977-2008 \text { as of }+2^{\circ} \mathrm{C}\right)\end{array}$ & $\begin{array}{l}\text { Rice } \\
\text { Wheat } \\
\text { Maize }\end{array}$ & \multicolumn{3}{|l|}{$\begin{array}{l}+1.7 \\
+2.32 \\
+1.49\end{array}$} \\
\hline Knox et al. (2011) & Crop models & $\begin{array}{l}\text { Rice } \\
\text { Wheat } \\
\text { Maize }\end{array}$ & \multicolumn{3}{|c|}{$\begin{array}{c}-60 \text { (Indian crops) } \\
+10 \text { (other South Asian countries) }\end{array}$} \\
\hline $\begin{array}{l}\text { Bandara and Cai } \\
\text { (2014) and Cai et } \\
\text { al. (2016) }\end{array}$ & $\begin{array}{l}\text { Systematic literature } \\
\text { review on all models }\end{array}$ & $\begin{array}{l}\text { Rice } \\
\text { Wheat } \\
\text { Maize }\end{array}$ & $\begin{array}{l}-2 \\
-13.7 \\
-17 \quad(20\end{array}$ & projection) & \\
\hline
\end{tabular}

Source: Chalise and Naranpanawa (2016)

\section{Empirical model in evaluating the impact of climate change on crop productivity}

On the one hand, it is not difficult to comprehend the qualitative impacts of climate change, when various economic variables are not included. On the other hand, when trying to quantify the economy-wide impacts of climate change, it is difficult to assess the effects of all factors that

\footnotetext{
2 The data are available for different $\mathrm{CO}_{2}$ emission scenarios of SRES (IPCC, 2000). The A2 scenario is employed for this study.
} 
are linked to climate change. Computable general equilibrium (CGE) models have long been used to examine the economy-wide effects of climate change at regular intervals. There has been an increasing trend of using global CGE models to examine the impact of climate change on individual countries and regions in the world. Some well-known examples are Nelson and Shively (2014), Müller and Robertson (2014), and Hertel et al. (2010). There have also been some efforts to investigate the impact of climate change on the South Asian region alone, with Bandara and Cai (2014), Cai et al. (2016), and Ahmed and Suphachalasai (2014) being recent examples. However, even though there is a growing body of literature on the topic, there is a lack of detailed country-specific studies as noted in the introduction.

This study uses a comparative-static multi-sectoral SAM based CGE model. This follows the tradition of the applied general equilibrium approach pioneered by Dixon, Parmenter, Sutton, and Vincent (1982), although its precise specification is more closely related to the South African CGE model developed by Horridge et al. (1995) and the poverty focussed Sri Lankan CGE model developed by Naranpanawa, Bandara, and Selvanathan (2011). As in any generic CGE model, producers are assumed to maximize profits subject to resource constraints, and consumers are assumed to maximize utility subject to budget constraints. The model also follows the neoclassical assumptions that export demand is negatively related to export prices; government expenditure is exogenously determined; consumers, producers and other agents are price takers, not price makers; and all product and factor markets follow the market-clearing assumption of demand equals supply.

For the purpose of simulation, A SAM constructed by Chalise and Naranpanawa (2016) for the year 2011, based on GTAP database version 9 (Aguiar, Narayanan, \& McDougall, 2016), was used as the database in the study. This model consists of 57 industries, 57 commodities, 3 factors, 7 household groups, and 10 skill/occupations types (see Appendices A and B). Household incomes are determined by their possession of 3 production factors (land, labour, 
and capital) and the market returns to these factors. The model comprises a set of nested constant elasticity of substitution (CES) functions for specifying production technologies and consumer demands for final goods and services. Households, government, enterprises and the rest of the world are the major agents that demand the final goods for their consumption. In the same way, CES is specified for an intermediate mix. Production of final goods and services is the combination of intermediate inputs and primary factors. The primary factors (land, labour, and capital) are aggregated through a CES function with a sub-set of CES functions for different types of occupations (for technical details of the core model, see Dixon et al., 1982).

In order to incorporate the key characteristics of household types, occupational skills and their linkages to the rest of the economy, this study extends the core model of the Australian ORANI model into two dimensions. First, given that a comparative analysis of climate change impacts is important for identifying winners and losers, this study follows Horridge et al. (1995) and introduces seven types of households on the basis of their characteristics, such as hectares of agricultural land in their possession and the household head's level of education (see Appendix A). The purpose of defining household groups in this way is to introduce heterogeneity with respect to urban/rural livelihood, mountain/hill/lowland topography, and high/low education. In doing so, the Nepalese National Living Standard Survey database (CBS, 2011b) is used to disaggregate household's final consumption and returns from primary factors. Second, to allow for differential effects in the employment of skill categories, 10 occupation types are introduced which explicitly model the heterogeneity of levels of income.

In this model, 'Rest of the world' is an agent that links the exports and imports of goods and services with the national economy. Furthermore, a CES function is specified to represent consumers' choices/decisions between domestic and imported goods, aggregating the final demand composite. The relative prices of goods and services are determined on the basis of real exchange rate as a numeraire, in that income in household level is only influenced by relative 
prices rather than absolute ones. To represent that savings equals investment, savings-driven income flow is assumed analogous to investments that are used only for final commodities. Capital and labour are perfectly mobile within a country but completely immobile in the rest of the world.

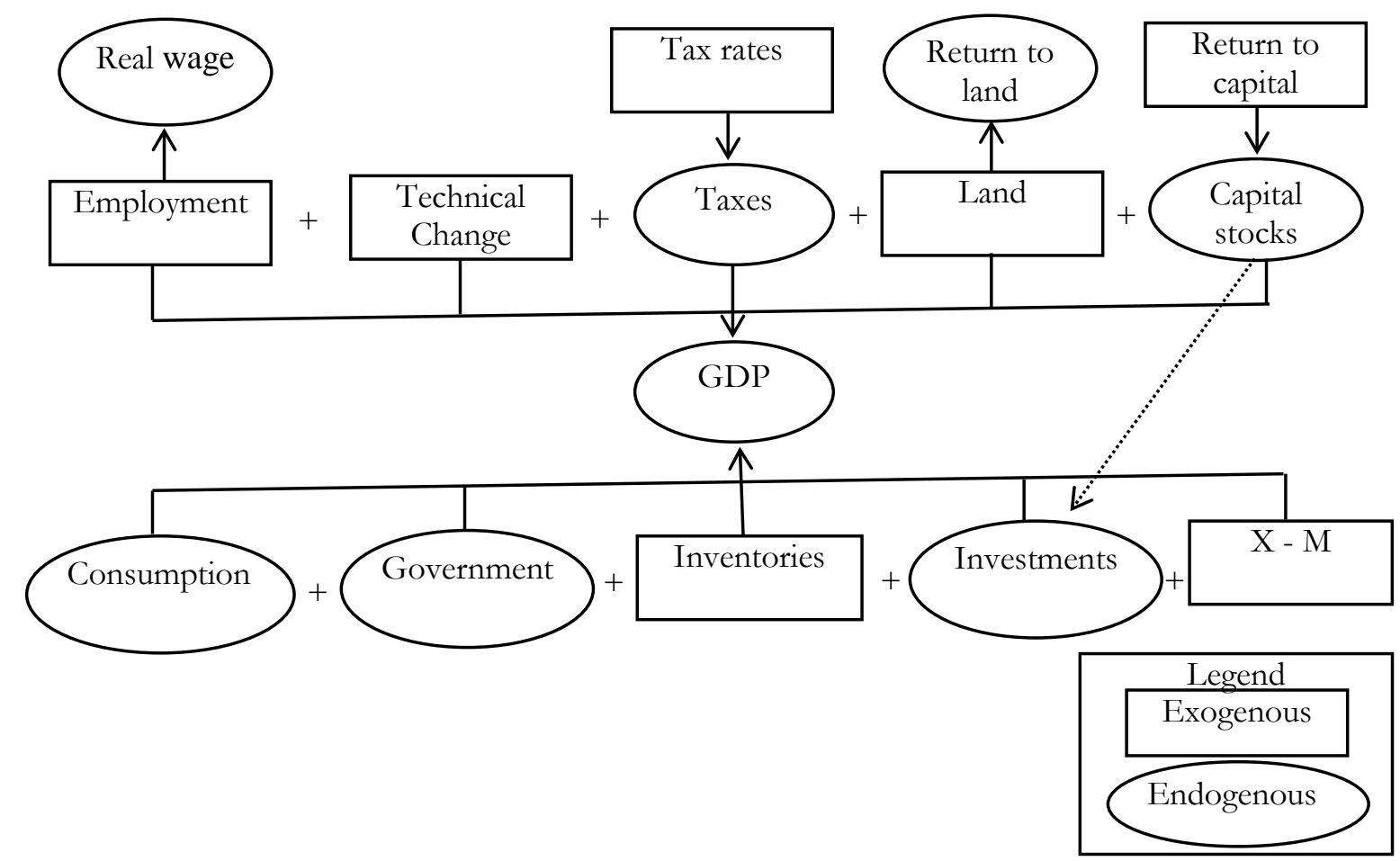

Diagram 1: Long-run closure used in the model

Source: Chalise and Naranpanawa (2016)

Typically, the model described above can be used for policy development using both shortrun and long-run economic environments known in the CGE literature as model closures. As there is a scientific consensus that the impacts of climate change can be realized distinctly within a 30-40 year period, a long-run closure is used for model simulations to avoid the uncertainty of transitional projection. This approach also evades the dangers of disequilibrium in the neoclassical approach such as the issue raised by Scrieciu (2007). Diagram 1 presents the long run macro-economic closure. From the income side, capital stocks are endogenous, while 
aggregate employment, total stocks of land, tax rates and technical changes are exogenous. This income-side closure indicates that the timescale now allows capital stocks to be installed; and that both the labour force and unemployment are determined by mechanisms outside of the model in the long-run. By fixing aggregate employment (i.e., labour supply is inelastic), the model allows wages to adjust in order to maintain labour market equilibrium as labour wages are no stickier in the long-run closure. Consequently, the total supply of each of the 10 occupations types are held fixed. The closure allows labour to move between industries but not across occupation types.

From the expenditure side, all aggregate GDP components are endogenous except for real inventories and the trade balance (exports-imports). The model holds the nominal trade balance as a fixed share of nominal GDP to reflect the idea that Nepal cannot infinitely borrow from abroad to fund a recurring trade deficit. Although the static CGE model developed in this paper does not have an explicit capital accumulation mechanism, the model allows investment for each industry to follow variations in capital stock (i.e., capital stocks adjust so that hold rates of return fixed and investment in each sector is proportional to the capital stock in that sector). The trade balance constraint in the model implies that changes in aggregate investment are accommodated by changes in domestic savings. Aggregate government demand follows aggregate household consumption to reflect the notion that higher household consumption requires more government services. Finally, the model maintains the exchange rate as the model's numeraire.

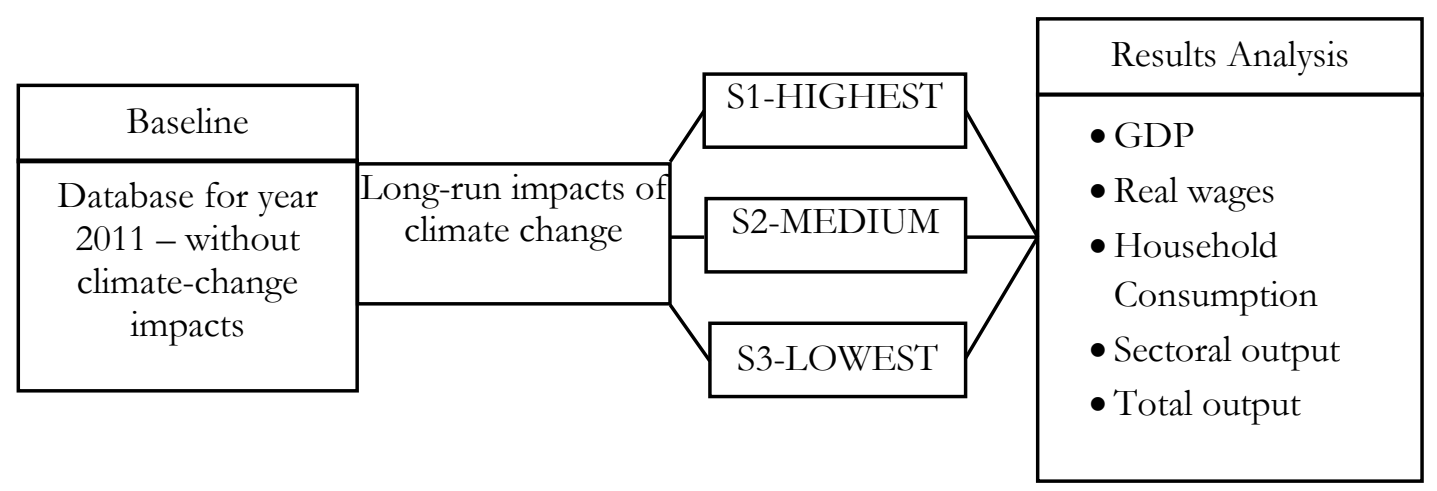

Diagram 2: Conceptual framework of the experiment 


\section{Table 2}

Agricultural productivity shocks (\%change) used in the model for three climate change impact scenarios

\begin{tabular}{llll}
\hline Sector & $\begin{array}{l}\text { Highest impact } \\
\text { scenario (S1) }\end{array}$ & $\begin{array}{l}\text { Medium impact } \\
\text { scenario (S2) }\end{array}$ & $\begin{array}{l}\text { Lowest impact } \\
\text { scenario (S3) }\end{array}$ \\
\hline Paddy Rice & $-15.20 \%$ & $-10.81 \%$ & $-1.20 \%$ \\
Wheat & $-17.10 \%$ & $-14.16 \%$ & $-2.30 \%$ \\
Maize & $-22.70 \%$ & $-19.08 \%$ & $-6.90 \%$ \\
Other Agricultural Sectors & $-17.30 \%$ & $-10.17 \%$ & $-4.80 \%$ \\
\hline
\end{tabular}

In order to address the link between climate change-induced loss of agricultural productivity and other parameters in the overall economy, this study focuses on 14 agricultural sectors ${ }^{3}$ in Nepal [out of the 57 sectors in GTAP database 2011 (Aguiar et al., 2016); see Appendix B]. From the impact assessment-related literature, average values of low, medium, and high productivity shocks of rice, wheat, maize, and other agricultural products have been obtained for use in the CGE model developed for this study (see Table 2). The shocks are used in the form of total factor productivity in the model. There are a number of reasons for taking an average of impacts. The first is to address the irregular trend of assessments developed in previous literature. The second is because of the non-uniformity of the methodology in the literature: some of the previous studies relied on crop models, while others aggregated the impacts. The final reason is that previous assessments have different time frames of impact assessment, with the risk of extremely low or high estimations. To be as accurate as possible, this study develops a set of shocks (change in agricultural productivity) from the averages of low, medium, and high impacts. The results are analysed (see Diagram 2 for the conceptual framework) on the basis of several key macro-variables: GDP, real wages, real consumption, and industry output.

\footnotetext{
${ }^{3}$ They are rice, wheat, cereal grains, vegetables, fruits, nuts, oil seeds, sugar cane, sugar beet, plant-based fibres, other crops, bovine-cattle-sheep-goats-horses, animal products, raw milk, wool, silk worms, forestry, and fishing.
} 


\section{Results}

The results obtained from the simulations of climate change impacts on Nepalese agriculture are analysed in two different stages, focusing on the changes in overall macro-variables and the impacts on different household groups. As mentioned in the methodology section, all simulated results are reported in the form of percentage changes from the baseline status. Any deviation of the variables from the base year (i.e., a year without climate change - 2011 was used in this model) to a future year (determined with distinct climate change impacts - 2080 was used in this model) were evaluated. As demonstrated in Diagram 2, the results for every variable are compared for three distinct climate change scenarios: S1 represents the highest, S2 a medium and S3 the lowest decrease in agricultural productivity.

\section{Table 3}

Deviation of real GDP, household income, real wages, household consumption and industry output from baseline in Nepal for high, medium, and low climate change-impact scenarios (unit $=\%$ )

\begin{tabular}{llll}
\hline Macro-variables & $\begin{array}{l}\text { Simulation 1 } \\
\text { Highest impact of } \\
\text { climate change (S1) }\end{array}$ & $\begin{array}{l}\text { Simulation 2 } \\
\text { Medium impact of } \\
\text { climate change (S2) }\end{array}$ & $\begin{array}{l}\text { Simulation 3 } \\
\text { Lowest impact of } \\
\text { climate change (S3) }\end{array}$ \\
\hline Real gross domestic product & -10.03 & -6.56 & -2.49 \\
Household income & -3.60 & -2.09 & -0.91 \\
Real wage & -13.35 & -8.67 & -3.30 \\
Household consumption & -9.34 & -6.05 & -2.32 \\
Industry output & -9.29 & -6.11 & -2.40 \\
\hline
\end{tabular}

Many analysts use the impact on GDP to examine the effects of climate change on crop productivity. The use of real GDP in terms of estimating changes in the Nepalese economy is important, as agriculture contributes around 36\% to national GDP. The simulation results show that the projected impact of climate change on agricultural productivity affects real GDP negatively. The real GDP is expected to decrease by $10.03 \%$ in the highest-impact scenario (S1), $6.56 \%$ in the medium-impact scenario (S2) and $2.49 \%$ in the lowest-impact scenario (S3), as 
shown in Table 3. A major factor of such a significant fall in GDP is the rapid decline in output of many agricultural products and other industrial outputs related to agriculture. As shown in Table 4, overall agricultural output and output of the major crops are likely to be affected by climate change-induced productivity loss in Nepalese agriculture.

\section{Table 4}

Deviation of sectoral output from baseline in Nepal, for high, medium, and low climate-change-impact scenarios $($ unit $=\%)$

\begin{tabular}{|c|c|c|c|}
\hline Sectoral output & $\begin{array}{l}\text { Simulation } 1 \\
\text { Highest impact of } \\
\text { climate change (S1) }\end{array}$ & $\begin{array}{l}\text { Simulation } 2 \\
\text { Medium impact of } \\
\text { climate change (S2) }\end{array}$ & $\begin{array}{l}\text { Simulation } 3 \\
\text { Lowest impact of } \\
\text { climate change (S3) }\end{array}$ \\
\hline Agriculture & -6.67 & -7.55 & -7.15 \\
\hline Rice & -7.22 & -5.26 & -0.80 \\
\hline Wheat & -5.45 & -3.83 & -1.28 \\
\hline Cereal grains & -8.43 & -6.36 & -2.43 \\
\hline Other crops & -12.98 & -8.24 & -3.62 \\
\hline Mining & -2.24 & -1.54 & -0.54 \\
\hline Manufacturing & -10.11 & -6.70 & -2.60 \\
\hline Utilities & -8.02 & -5.20 & -1.97 \\
\hline Services & -7.53 & -4.97 & -1.82 \\
\hline
\end{tabular}

Overall, sectoral outputs are projected to fall heavily due to climate change (see Table 4), and commodities prices are expected to increase significantly. Table 5 shows the projected increase in prices of agricultural and other commodities. As climate change induces huge impacts on Nepalese agriculture, the results show a significant increase in the price of agricultural products in comparison to other commodities. This will lead to a large crisis in agricultural products in the future. Although rice is a major part of the agricultural economy in Nepal, cereal crops also play an important role in rural livelihoods, especially in the mid-hills and rural mountains (CBS, 2012). Therefore, the expected increase in the price of cereal crops in Nepal (see Table 5) will also bring about a huge food security problem in future. 


\section{Table 5}

Deviation of price of commodities and rentals of agricultural land from baseline in Nepal, for high, medium, and low climate-change-impact scenarios (unit $=\%$ )

\begin{tabular}{lllllll}
\hline Sectors & \multicolumn{2}{l}{$\begin{array}{l}\text { Simulation 1 } \\
\text { Highest impact of } \\
\text { climate change (S1) }\end{array}$} & $\begin{array}{l}\text { Simulation 2 } \\
\text { Medium impact of } \\
\text { climate change (S2) }\end{array}$ & $\begin{array}{l}\text { Simulation 3 } \\
\text { Lowest impact of } \\
\text { climate change (S3) }\end{array}$ \\
\cline { 2 - 7 } & Price & $\begin{array}{l}\text { Land } \\
\text { rentals }\end{array}$ & Price & $\begin{array}{l}\text { Land } \\
\text { rentals }\end{array}$ & Price & $\begin{array}{l}\text { Land } \\
\text { rentals }\end{array}$ \\
\hline Rice & 26.09 & 39.98 & 18.73 & 28.14 & 0.95 & 1.05 \\
Wheat & 36.04 & 65.71 & 31.94 & 60.01 & 3.24 & 4.48 \\
Cereal grains & 44.96 & 81.35 & 40.11 & 74.85 & 13.45 & 24.46 \\
Other crops & 22.43 & 15.56 & 12.82 & 6.58 & 6.11 & 5.47 \\
Other commodities & 2.36 & N/A & 1.58 & N/A & 0.49 & N/A \\
\hline
\end{tabular}

A substantial decrease in sectoral outputs, primarily in agricultural products, influences household income and consumption. As real GDP (from the expenditure side; see the last row of Diagram 1) is determined by the sum of household consumption, investment, government expenditure, and net exports, the significant decrease in household consumption results in a huge decline in real GDP. Overall household consumption, which is shown in Table 3, clearly illustrates the important role that household expenditure plays in maintaining GDP. To understand the effects of climate change-induced productivity loss, it is important to see the differences in impacts between different household groups. Table 6 shows the changes in consumption for different household groups and clearly differentiates the spread in impacts, as urban households are expected to experience a greater decrease in consumption than rural ones. The main reason for this is that urban households do not produce agricultural commodities and depend on highly priced products from the producers, who primarily belong to rural households.

The impact of climate change on land rentals is also shown in Table 5. Higher land rentals create higher costs of production that ultimately result in an increase in the demand for land for a particular industry, which is fulfilled by decreasing real wages significantly in general 
equilibrium models. This also disturbs labour and household income. The decrease in household consumption (see Table 6) is an outcome of the decrease in household income. In this way, the simulation results show that the increase in land rentals is expected to overwhelm the decrease in wages and interests, resulting in a significant decrease in real GDP in Nepal.

\section{Table 6}

Deviation of household income and consumption from baseline in Nepal, for high, medium, and low climate-change-impact scenarios (unit $=\%$ )

\begin{tabular}{lllllll}
\hline Households & \multicolumn{2}{l}{$\begin{array}{l}\text { Simulation 1 } \\
\text { Highest impact of }\end{array}$} & \multicolumn{2}{l}{$\begin{array}{l}\text { Simulation 2 } \\
\text { Medium impact of } \\
\end{array}$} & $\begin{array}{l}\text { Simulation 3 } \\
\text { climate change (S2) }\end{array}$ & $\begin{array}{l}\text { lowest impact of } \\
\text { climate change (S3) }\end{array}$ \\
\cline { 2 - 7 } & INC & CON & INC & CON & INC & CON \\
\hline Rural land less & -12.43 & -9.27 & -8.11 & -6.02 & -3.09 & -2.30 \\
Rural land small & -10.85 & -7.66 & -7.01 & -4.90 & -2.69 & -1.89 \\
Rural land medium & -10.25 & -7.05 & -6.63 & -4.53 & -2.56 & -1.76 \\
Rural land large & -10.27 & -7.07 & -6.67 & -4.56 & -2.58 & -1.78 \\
Urban low education & -14.18 & -11.05 & -9.26 & -7.18 & -3.52 & -2.72 \\
Urban medium education & -14.22 & -11.10 & -9.30 & -7.23 & -3.54 & -2.75 \\
Urban high education & -13.55 & -10.41 & -8.86 & -6.78 & -3.38 & -2.59 \\
\hline
\end{tabular}

Note: $\quad$ INC $=$ total household income and $\mathrm{CON}=$ household consumption

Understanding the substantial loss in GDP requires an estimation of the change in the individual parameters that determine the real GDP from the income side: land rents, labour wages, capital interests, profits, and taxes. The major components of household income are rental income, wages, and interest. As total employment is constant in the long-run closure used in the model, labour from other sectors moves to agriculture-based industries (see Table 7). As the cost of living goes up due to extreme inflationary prices, overall real wages decrease significantly. The huge decrease in sectoral output in manufacturing and services (seen in Table 4 above) leads to a considerable decrease in labour income in urban households, and results in a greater decrease in total income in those households than in rural households (Table 6). 


\section{Table 7}

Deviation of employment in different occupational types from baseline in Nepal, for high, medium, and low climate-change-impact scenarios (unit $=\%$ )

\begin{tabular}{llll}
\hline Occupational types & $\begin{array}{l}\text { Simulation 1 } \\
\text { Highest impact of } \\
\text { climate change (S1) }\end{array}$ & $\begin{array}{l}\text { Simulation 2 } \\
\text { Medium impact of } \\
\text { climate change (S2) }\end{array}$ & $\begin{array}{l}\text { Simulation 3 } \\
\text { Lowest impact of } \\
\text { climate change (S3) }\end{array}$ \\
\hline Self-employed & -4.37 & -2.91 & -1.04 \\
High skilled professionals & -5.35 & -3.53 & -1.28 \\
Medium skilled professionals & -3.92 & -2.59 & -0.93 \\
Government and NGO clerks & -5.34 & -3.50 & -1.27 \\
Industry workers & 1.22 & 0.76 & 0.31 \\
Artisans and handicraftsmen & -3.50 & -2.35 & -0.87 \\
Informal & -1.04 & -0.67 & -0.27 \\
Agricultural owners & 3.23 & 2.14 & 0.77 \\
Agricultural workers & 3.46 & 2.28 & 0.85 \\
Agriculture subsistence farmers & 8.77 & 5.83 & 2.09 \\
\hline
\end{tabular}

The climate change-induced productivity loss therefore has negative impacts on the overall Nepalese economy. These impacts extend beyond agriculture-related industries to all other remaining sectors, including manufacturing and services. As Nepalese manufacturing and service sectors are linked with agricultural products, a small change in agricultural productivity creates multiplier effects in the overall economy. Table 4 also depicts that manufacturing outputs will decrease by around 10\% due to crop productivity loss. A similar situation is expected in the utility and services sectors due to climate change-induced loss of agriculture productivity.

It is clear from the empirical evidence surrounding climate change impacts on agriculture in Nepal in this study, that the overall view of climate change literature is supported (for example, Bartlett, Bharati, Pant, Hosterman, \& McCornick, 2010; Chalise \& Naranpanawa, 2016; Cline, 2007; Karki \& Gurung, 2012; MOAC, 2011; Thapa \& Joshi, 2011). However, as some of the previous studies of Nepal (see CBS, 2011a; Cockburn, 2001; Hertel et al., 2010; World Bank, 1998, 2005) have not captured the economy-wide impacts of climate change on Nepalese 
agriculture, this paper is a step forward in the analysis of the linkages of climate change and agricultural productivity - a major contribution in overall climate change literature.

\section{Policy implications and conclusions}

Using a country-specific CGE model of the Nepalese economy, this paper has explored the macro- and micro-economic effects of climate change impacts on Nepalese agriculture. As highlighted in the results section, the simulation results of this study have revealed that Nepalese agriculture will be severely impacted by climate change-induced productivity loss by 2080 . Similarly, a huge increase in commodity prices will create a great challenge for urban livelihoods. As demonstrated in the previous section, real GDP is expected to decline significantly as the agricultural sector contributes a large proportion to GDP.

The results of this study are highly consistent with the results of previous studies. As Nepalese agriculture is the most affected among South Asian countries (according to Bandara \& Cai, 2014, p. 459), the results above show that a climate-induced reduction in food production is projected to exert an upward pressure on food prices, which will result in food security problems in Nepal. The prices of rice, wheat, and cereal grains - the three major staple foods in Nepalare expected to rise significantly by around $26 \%, 36 \%$, and $44 \%$ respectively by 2080 . As Nepal imports most of its staple foods from other South Asian countries, the situation will become challenging as global food prices are expected to increase significantly in the future (Elbehri, 2015; Hertel et al., 2010). If the absence of any adaptation to climate change continues, the resulting massive increase in commodity prices will pose great challenges for rural smallholders' livelihoods. As an outcome of these results, real GDP is expected to decrease markedly.

Some key policy implications related to climate change, particularly from a broader perspective, can be drawn from this study. As Nepal is a member of the least developed countries, the future impacts of climate change can be predicted to be severe, especially for 
Nepalese farmers who may be unable to adopt the adaptation strategies. Largely due to its static adaptation capacity, ${ }^{4}$ the vulnerability projection according to the A2 emission scenario in 2050 (IPCC, 2000) places Nepal in the significantly vulnerable category. Although farmers have already initiated some useful adaptation practices on their own, without any support from the government or any other organisations, large-scale planned strategies to support them are urgently required. Based on the results of this study, as well as the likelihood of more frequent flash floods in low-land paddy farms and serious landslides in hilly maize farms in Nepal, it is important to invest more in the control of excess water flows and on forest management technology. In addition, serious consideration should be given to measures designed to prevent, mitigate, and adapt to water deficiency in Nepalese cropping agriculture. As Salami, Shahnooshi, and Thomson (2009) suggest, cropping rotation and changes in the cropping calendar, such as fairly simple modifications in vegetable growing (e.g. changed planting dates, and different maturity-date cultivars), can reduce likely climate change-induced losses in future decades.

To conclude, future research is recommended to address the limitations of this study. The study has not explored the bio-physical aspects of climate change impacts in detail, including those determining the actual cost of damage to crops and human capital (e.g., impacts in biophysical requirements due to direct or indirect imbalance in water, or due to labour productivity). Therefore, a study to evaluate all the factors responsible for productivity loss due to climate change, and the adaptation practices that have been started in Nepal, is required. Furthermore, a numerical assessment of the impacts and possible adaptation to climate change would require a much expanded modelling framework, and/or thoughtful assumptions of the extent and distribution of such problems. Despite the above limitations, the results of this study provide evidence that serious policy planning and implementation of adaptation strategies are required in the near future to help reduce the negative impact of climate change on the agricultural sector.

\footnotetext{
${ }^{4}$ According to the vulnerability projection report, vulnerability is a function of exposure, sensitivity and adaptive capacity.
} 
Moreover, although there has already been some focus on assessing and comparing the impacts of climate change-induced productivity loss on the overall Nepalese economy, with and without adaptation in agriculture (see Chalise \& Naranpanawa, 2016) it is still particularly important to assess household poverty in Nepal in the future studies.

\section{Appendix A}

Table A1 Household groups and occupation types

\begin{tabular}{|c|c|}
\hline Grouping & Income groups and their characteristics \\
\hline Households & $\begin{array}{l}\text { 1. Rural landless farmer } \\
\text { 2. Rural land small farmer (less than } 0.5 \mathrm{Bigha}^{*} \text { ) } \\
\text { 3. Rural land medium farmer (between } 0.51 \text { and } 2.50 \text { Bigha) } \\
\text { 4. Rural land large farmer (more than } 2.51 \mathrm{Bigha} \text { ) } \\
\text { 5. Urban low education (household head having less than class/grade } 10 \\
\text { education) } \\
\text { 6. Urban medium education (household head having both secondary school } \\
\text { certificate and higher secondary certificate) } \\
\text { 7. Urban high education (household head having bachelor and high degrees) }\end{array}$ \\
\hline Occupations & $\begin{array}{l}\text { 1. Self-employed labourers } \\
\text { 2. High skilled professionals and managers } \\
\text { 3. Medium skilled professionals and technicians } \\
\text { 4. Government and non-government office clerks (employees) } \\
\text { 5. Workers (transport, mechanics and other industrial workers) } \\
\text { 6. Artisans and handicraftsmen } \\
\text { 7. Informal (street-vendors and non-economic services nes) } \\
\text { 8. Agricultural owners/administrators } \\
\text { 9. Agricultural workers } \\
\text { 10. Agriculture subsistence farmers }\end{array}$ \\
\hline
\end{tabular}

Note: Bigha* is a unit of land mostly used in the rural part of Nepal. One Bigha $=0.16055846$ hectares.

Adapted from: Chalise and Naranpanawa (2016) 


\section{Appendix B}

Table B1 List of industries

\begin{tabular}{|c|c|}
\hline Sectors & Industries \\
\hline Agriculture & $\begin{array}{l}\text { 1. Paddy rice } 2 \text {. Wheat 3. Cereal grains nec } 4 \text {. Vegetables, fruit and nuts } 5 \text {. Oil seeds } \\
\text { 6. Sugar cane, sugar beet } 7 \text {. Plant-based fibres } 8 \text {. Crops nec } 9 \text {. Bovine cattle, sheep } \\
\text { and goats, horses } 10 \text {. Animal products nec } 11 \text {. Raw milk } 12 \text {. Wool, silk-worm } \\
\text { cocoons } 13 \text {. Forestry } 14 \text {. Fishing }\end{array}$ \\
\hline Mining & 15. Coal 16. Oil 17. Gas 18. Minerals nec \\
\hline Manufacturing & $\begin{array}{l}\text { 19. Bovine cattle, sheep and goat, horse meat products 20. Meat products nec } 21 . \\
\text { Vegetable oils and fats 22. Dairy products } 23 \text {. Processed rice } 24 \text {. Sugar 25. Food } \\
\text { products nec } 26 \text {. Beverages and tobacco products } 27 \text {. Textiles } 28 \text { Wearing apparel } \\
\text { 29. Leather products } 30 \text {. Wood products } 31 \text {. Paper products, publishing } 32 . \\
\text { Petroleum, coal products } 33 \text {. Chemical, rubber, plastic products } 34 \text {. Mineral } \\
\text { products nec } 35 \text {. Ferrous metals } 36 \text { Metals nec } 37 \text {. Metal products } 38 \text {. Motor } \\
\text { vehicles and parts } 39 \text {. Transport equipment nec } 40 \text {. Electronic equipment } 41 . \\
\text { Machinery and equipment nec } 42 \text {. Manufacturers nec }\end{array}$ \\
\hline Utilities & 43. Electricity 44. Gas manufacture, distribution 45. Water \\
\hline Services & $\begin{array}{l}\text { 46. Construction 47. Trade 48. Transport nec } 49 \text {. Water transport } 50 \text {. Air transport } \\
\text { 51. Communication } 52 \text {. Financial services nec } 53 \text {. Insurance } 54 \text {. Business services } \\
\text { nec 55. Recreational and other services } 56 \text {. Public administration and defense, } \\
\text { education, health } 57 \text {. Dwellings }\end{array}$ \\
\hline
\end{tabular}

Note: This table is based on the global trade analysis project (GTAP) database (Aguiar et al., 2016) for the base year 2011.

\section{References}

Aguiar, A., Narayanan, B., \& McDougall, R. (2016). An Overview of the GTAP 9 Data Base. 2016, 1(1), 28. doi:http://dx.doi.org/10.21642/igea.010103af

Ahmed, M., \& Suphachalasai, S. (2014). Assessing the costs of climate change and adaptation in South Asia Retrieved from https://think-asia.org/handle/11540/46

Auffhammer, M., Ramanathan, V., \& Vincent, J. R. (2012). Climate change, the monsoon, and rice yield in India. Climatic Change, 111(2), 411-424. doi:http://dx.doi.org/10.1007/s10584011-0208-4

Bandara, J. S., \& Cai, Y. (2014). The impact of climate change on food crop productivity, food prices and food security in South Asia. Economic Analysis and Policy, 44(4), 451-465. doi:http://dx.doi.org/10.1016/i.eap.2014.09.005

Bartlett, R., Bharati, L., Pant, D., Hosterman, H., \& McCornick, P. (2010) Climate change impacts and adaptation in Nepal. IWMI Working Paper (pp. 35). Colombo, Sri Lanka: International Water Management Institute. 
Byjesh, K., Kumar, S., \& Aggarwal, P. (2010). Simulating impacts, potential adaptation and vulnerability of maize to climate change in India. Mitigation and Adaptation Strategies for Global Change, 15(5), 413-431. doi:http://dx.doi.org/10.1007/s11027-010-9224-3

Cai, Y., Bandara, J. S., \& Newth, D. (2016). A framework for integrated assessment of food production economics in South Asia under climate change. Environmental Modelling \& Software, 75, 459-497. doi:http://dx.doi.org/10.1016/i.envsoft.2015.10.024

CBS. (2011a). CBS view on poverty in Nepal 2010-11. Retrieved from http://cbs.gov.np/nada/index.php/catalog/37

CBS. (2011b). Nepal living standards survey. Retrieved from http://cbs.gov.np/nada/index.php/catalog/37

CBS. (2012). Statistical information on Nepalese agriculture 2011/2012. Retrieved from http://www.moad.gov.np/downloadfile/yearbook2012 1363677455.pdf

CBS. (2014). Statistical pocket book of Nepal. Retrieved from http://cbs.gov.np/publications/Statistical\%20Pocket $\% 20$ Book\%202014

Chalise, S. (2012). Combating Climate Change: A Real Threat to Nepal (S. Lynch Ed.). Germany: Lambert Academic Publishing.

Chalise, S., Maraseni, T. N., \& Maroulis, J. (2015). Adapting to climate variability: the views of peasant farmers in Nepal. International Journal of Global Warming, 7(3), 380-394. doi:http://dx.doi.org/doi:10.1504/IJGW.2015.069369

Chalise, S., \& Naranpanawa, A. (2016). Climate change adaptation in agriculture: A computable general equilibrium analysis of land-use change in Nepal. Land Use Policy, 59, 241-250. doi:http://dx.doi.org/10.1016/j.landusepol.2016.09.007

Chhetri, N., Chaudhary, P., Tiwari, P. R., \& Yadaw, R. B. (2012). Institutional and technological innovation: Understanding agricultural adaptation to climate change in Nepal. Applied Geography, 33, 142-150. doi:http://dx.doi.org/10.1016/j.apgeog.2011.10.006

Cline, W. R. (2007). Global warming and agriculture, impact estimates by country Retrieved from http://www.cgdev.org/publication/9780881324037-global-warming-and-agriculture-impactestimates-country

Cockburn, J. (2001). Trade Liberalisation and Poverty in Nepal: A Computable General Equilibrium Micro Simulation Analysis. Retrieved from

Dixon, P. B., Parmenter, B. R., Sutton, J., \& Vincent, D. P. (1982). ORANI, a multisectoral model of the Australian economy. Amsterdam ; New York : New York, N.Y: North-Holland Pub. Co. ; Sole distributors for the U.S.A. and Canada, Elsevier Science Pub. Co.

Elbehri, A. (2015). Climate change and food systems - global assessments and implications for food security and trade Retrieved from http://www.fao.org/documents/card/en/c/2d309fca-89be-481f-859e$\underline{72 \mathrm{~b} 27 \mathrm{a} 3 \mathrm{ea} 5 \mathrm{dc} /}$

Elbehri, A., \& Burfisher, M. (2015). Economic modelling of climate impacts and adaptation in agriculture: a survey of methods, results and gaps. In A. Elbehri (Ed.), Climate Change and Food Systems - Global Assessments and Implications for Food Security and Trade. Rome: FAO.

Garnaut, R. (2013). Removing Climate Change as a Barrier to Economic Progress: Twentysecond Colin Clark Memorial Lecture November 2012. Economic Analysis and Policy, 43(1), 31 47. doi:http://dx.doi.org/10.1016/S0313-5926(13)50002-6

Hertel, T. W., Burke, M. B., \& Lobell, D. B. (2010). The poverty implications of climate-induced crop yield changes by 2030. Global Environmental Change, 20(4), 577-585. doi:http://dx.doi.org/10.1016/i.gloenvcha.2010.07.001

Horridge, M., Parmenter, B. R., Cameron, M., Joubert, R., Suleman, A., \& de Jongh, D. (1995). The macroeconomic, industrial, distributional and regional effects of government spending programs in South Africa. Working Paper. Monash University. Retrieved from https://ideas.repec.org/p/cop/wpaper/g-109.html

Iglesias, A., \& Rosensweig, C. (2010). Effects of Climate Change on Global Food Production from SRES Emissions and Socioeconomic Scenarios. from NASA Socioeconomic Data and 
Applications Center (SEDAC) http://sedac.ciesin.columbia.edu/data/set/crop-climateeffects-climate-global-food-production

IPCC. (2000). Emissions Scenarios. Retrieved from http://www.ipcc.ch/ipccreports/sres/emission/index.php?idp $=0$

IPCC. (2013). Climate Change 2013 Summary for Policymakers. Retrieved from http://www.ipcc.ch/report/ar5/wg1/

Joshi, N. P., Maharjan, K. L., \& Piya, L. (2011). Effect of Climate Variables on Yield of Major Food-crops in Nepal. Journal of Contemporary India Studies: Space and Society, Hiroshima University, 1,19-26.

Karki, \& Gurung, A. (2012). An Overview of Climate Change And Its Impact on Agriculture: a Review From Least Developing Country, Nepal. International Journal of Ecosystem, 2(2), 19-24. doi:http://dx.doi.org/10.5923/i.ije.20120202.03

Knox, J. W., Hess, T. M., Daccache, A., \& Perez Ortola, M. (2011). What are the projected impacts of climate change on food crop productivity in Africa and South Asia? DFID Systematic Review, Final Report (pp. 77 pp.). Cranfield, UK: Cranfield University.

Kumar, K. S. K. (2011). Climate sensitivity of Indian agriculture: do spatial effects matter? Cambridge Journal of Regions, Economy and Society, 4(2), 221-235. doi:http://dx.doi.org/10.1093/cjres/rsr004

Kumar, K. S. K., \& Parikh, J. (2001). Indian agriculture and climate sensitivity. Global Environmental Change, 11(2), 147-154. doi:http://dx.doi.org/10.1016/S0959-3780(01)00004-8

Malla, G. (2008). Climate Change and its Impact on Nepalese Agriculture. The Journal of Agriculture and Environment, 9, 62-71.

MOAC. (2011). Climate Change Adaptation and Disaster Risk. Management in Agriculture. Retrieved from http://www.fao.org/docrep/015/an713e/an713e00.pdf

Müller, C., \& Robertson, R. D. (2014). Projecting future crop productivity for global economic modeling. Agricultural Economics, 45(1), 37-50. doi:http://dx.doi.org/10.1111/agec.12088

NAPA. (2010). Ministry of Environment. Government of Nepal - National Adaptation Programme of Action (NAPA) to Climate Change. Retrieved from http://archnet.org/publications/7221

Naranpanawa, A., Bandara, J. S., \& Selvanathan, S. (2011). Trade and poverty nexus: A case study of Sri Lanka. Journal of Policy Modeling, 33(2), 328-346. doi:http://dx.doi.org/10.1016/i.jpolmod.2010.08.008

NCVST. (2009). Vulnerability through the eyes of vulnerable: Climate change induced uncertainties and Nepal's development predicaments. Retrieved from http://i-s-e-t.org/resources/major-programreports/vulnerability-through-the-eyes-of-vulnerable.html

Nelson, G. C., \& Shively, G. E. (2014). Modeling climate change and agriculture: an introduction to the special issue. Agricultural Economics, 45(1), 1-2. doi:http://dx.doi.org/10.1111/agec.12093

Pokhrel, D. M., \& Thapa, G. B. (2007). Are marketing intermediaries exploiting mountain farmers in Nepal? A study based on market price, marketing margin and income distribution analyses. Agricultural Systems, 94(2), 151-164. doi:http://dx.doi.org/10.1016/j.agsy.2006.08.004

Poudel, S., \& Kotani, K. (2013). Climatic impacts on crop yield and its variability in Nepal: do they vary across seasons and altitudes? Climatic Change, 116(2), 327-355. doi:http://dx.doi.org/10.1007/s10584-012-0491-8

Salami, H., Shahnooshi, N., \& Thomson, K. J. (2009). The economic impacts of drought on the economy of Iran: An integration of linear programming and macroeconometric modelling $\begin{array}{llll}\text { approaches. } & \text { Ecological } & \text { Economics, } & \text { 68(4), }\end{array}$ doi:http://dx.doi.org/10.1016/j.ecolecon.2008.12.003

Scrieciu, S. S. (2007). The inherent dangers of using computable general equilibrium models as a single integrated modelling framework for sustainability impact assessment. A critical note on Böhringer and Löschel (2006). Ecological Economics, 60(4), 678-684. doi:http://dx.doi.org/10.1016/j.ecolecon.2006.09.012 
Thapa, S., \& Joshi, G. R. (2011). A Ricardian analysis of the climate change impact on Nepalese agriculture. Retrieved from https://ideas.repec.org/p/pra/mprapa/29785.html

UNFCCC. (2015). Adoption of the Paris agreement. Retrieved from https://unfccc.int/resource/docs/2015/cop21/eng/109r01.pdf

World Bank. (1998). Poverty in Nepal: At the turn of the twenty-first century. Retrieved from http://documents.worldbank.org/curated/en/920121468758113230/Nepal-Poverty-inNepal-at-the-turn-of-the-twenty-first-century

World Bank. (2005). Nepal development policy review: Restarting growth and poverty reduction. Retrieved from https://openknowledge.worldbank.org/handle/10986/8530

World Bank. (2012). Turn down the heat: Why a $4^{\circ} \mathrm{C}$ warmer world must be avoided. Retrieved from http://documents.worldbank.org/curated/en/865571468149107611/Turn-down-the-heatwhy-a-4-C-warmer-world-must-be-avoided 